\title{
Supply Chain Management and Organizational Performance: An Empirical Investigation with Special to E-Commerce Organizations in India
}

\author{
M. Sreenivasulu Reddy, P. Raghunadha Reddy
}

\begin{abstract}
Supply chain management (SCM) is a crucial strategic driver for increasing operational performance and maximizing the achievement of organizational objectives, such as improved productivity, improved customer service and enhanced profitability. The age of both market globalization and outsourcing has started, and many companies tend to manage their supply chain and logistics activities. Most of these organizations understand that SCM needs to be tested for its performance in order to create an effective and efficient supply chain. Since e-commerce buys and sells goods over the Internet, in addition to payment between the two parties, it is the transfer of goods that also needs to occur in a correct and timely manner, hence the need for the supply chain. The supply chain is the most critical element for companies to boom in e-commerce, which needs to be quick, uninterrupted and safe. The competition is fierce because not one or two, but hundreds of e-commerce companies are competing for market share, each finding and creating specific strategies for sale and distribution. The present study is an attempt to examine various issues of supply chain management in the E-Commerce context. Although there is a lack of literature in this context, the current study critically reviewed the current literature and built a questionnaire with the inputs from leading e-commerce managers by identifying the main supply chain management issues such as preparation, inbound, outbound, returns, orders and trying to find the effect of these variables on organizational efficiency. A sample size of 100 employees employed in supply chain departments at different levels of five leading e-commerce fashion \& lifestyle organizations in India was taken for a questionnaire survey as a sampling unit. The study found fascinating insights of supply chain management in e-commerce, which eventually benefit the marketers to design more effective supply chain management. Further, this study becomes a gap filler for the existing literature deficiency in the Indian context and an e-commerce context.

Key Words: SCM, Operational Performance, Globalization, ECommerce Organizations, Competition.
\end{abstract}

\section{INTRODUCTION}

The introduction of e-commerce technology has created countless opportunities for companies to improve their supply chains and streamline them.

Manuscript received on February 12, 2021.

Revised Manuscript received on February 19, 2021.

Manuscript published on February 28, 2021.

* Correspondence Authors

M. Sreenivasulu Reddy*, Research Scholar, Department of Management Studies, School of Commerce, Management and Computer Science, Sri Venkateswara University, Tirupati. Email ID: sreenu.sr@gmail.com

Dr. P. Raghunadha Reddy, Professor, Department of Management Studies, School of Commerce Tirupati., Management and Computer Science, Sri Venkateswara University, Tirupati Email ID: sairaghubhanu@gmail.com

(c) The Authors. Published by Blue Eyes Intelligence Engineering and Sciences Publication (BEIESP). This is an open access article under the CC BY-NC-ND license (http://creativecommons.org/licenses/by-nc-nd/4.0/)
A supply chain is a network of facilities and distribution options to cooperate to design, create, distribute, and support products-commerce for the entire network of companies. It is an emerging technology which is also useful for clients and companies.

Websites and successful Supply Chain Management are major requirements for an e-commerce company (SCM). Despite location problems, SCM focuses on the raw procurement, manufacture of the product, and delivery of the product before the product reaches the customer. The 'supply chain' means the movement of raw materials to the plant and customers (finished goods). In the manufacturing sector, this supply chain management plays a critical role for ages and functions as an integral part of the overall production process. Usually, each company maintains a fully integrated supply chain division that ensures smooth products output and timely delivery. This feature has taken on an all-new sense with the advent of e-commerce, where the functioning of the supply chain may collapse or establish an organization. Supply Chain Management encompasses business processes from production, sourcing, transport, and physical delivery to end-users of goods. Effective management of the supply chain coordinates and incorporates all these processes into a smooth method. In addition to the divisions of the company, SCM works with partners that include distributors, airlines, third-party firms, and providers of information systems. Any business transaction that includes the transfer of information through the Internet refers to electronic commerce or e-commerce. It encompasses different business operations by definition that use the Internet as a medium for either information exchange or monetary transaction, or both at times. Because e-commerce is the purchasing and sale of products over the Internet, the movement of goods often needs to occur in a correct and timely manner, in addition to payment between the two parties, thereby ensuring an efficient supply chain. The supply chain is the most critical element that needs to be quick, uninterrupted, and safe for companies to boom in e-commerce. The business is fierce because one or two of them are not. Hundreds of e-commerce firms, however, fight for market share, each identifying and developing innovative sales and delivery strategies.

\section{LITERATURE REVIEW}

The literature review's motive is to collect and generate structure references related to the research problem from research articles, books, and other reliable and valid sources of information published in the recent past. 
Primarily, the article search was processed based on the keywords - SCM and organizational performance. Most of the papers reviewed supported the current research work marginally. However, some of the most cited relevant studies that investigated the relationship between supply chain management and organizational performance were reviewed as follows:

Neely (1998) recognizes seven factors to be included in the management schedule for performance measurement: changing the nature of work, increasing competitiveness, unique development programs, national and international quality awards, changing organizational responsibilities, changing external criteria, and the power of information technology.

Larson and Halldorsson (2002) argue that four significant forecast factors, inventory planning, supply chain efficiency and accuracy of information, drive an enterprise in today's business climate. Effective management of these variables can assist the organization to efficiently and effectively deliver the product or service to its customer at the right time, location, and price.

According to Martinez (2005), there are eight positive effects of PM. They are: to focus people's attention on what is essential to the company; get business improvement; improve customer satisfaction; increase productivity; align operational performance with strategic objectives; improve people satisfaction; align people behaviours towards continuous improvement; improve company reputation.

Kurien and Qureshi (2011) presented a paper aimed at updating the supply chain performance assessment literature to clarify existing processes, recognize gaps, and formulate a future research agenda. An overview and comparison of the performance metrics used in supply chain models was also discussed in this paper. The authors argued that in order to achieve their operational objectives, effective supply chains use integrated measurement systems as a vehicle. A comparative study of some of the most commonly cited systems for performance assessment has been carried out. This suggests that it is important to determine the validity of many of the measurement structures through further research. The authors further suggested that it is difficult due to the complexity of these processes to select acceptable supply chain performance metrics.

Jayaraman et al (2013) researched the structure and activities of the Indian e-commerce industry. They find that supply chain management, reverse logistics, infra-issues relating to prepaid purchases vis-à-vis COD (Cash-OnDelivery) are all to be matured for the survival of online businesses, apart from the lack of investment resources. Two examples were studied: an online fashion shop with some distinctive features and a bouquet of products offered by another online venture. These two companies are at the two ends of the Indian online industry's continuum, with the latter being the biggest in terms of scale and the oldest in terms of its existence (Flipkart was started in 2007). The former is a newly founded specialty retailer. Although some of their problems are prevalent, some variations can lead them to follow their businesses in different ways. The authors have attempted to study and bring out the salient features and have proposed some thoughts on the path forward for the e-commerce industry.

Nimna (2017) explored the role of supply chain management in e-commerce practices and described the challenges for the e-commerce industry in developing and sustaining a supply chain management system. She concentrated mainly on globalization, improper data flow, payment gateway difficulties, and low internet penetration. In the e-commerce sector, the analysis found the following benefits of efficient supply chain management: enhanced supply chain network, enhanced CRM, global trade, virtual firms, reduced delays, cost reduction, and customer satisfaction. Although the role of supply chain management in e-commerce industries has been studied in this paper, it failed to provide any empirical conclusion.

Jamal Ahmed (2019) examined the possible advantages of cooperation in the supply chain to achieve operational efficiency. This is an empirical investigation conducted by Pakistan's automotive industry supply chain department. The study introduced an organizational performance conceptual structure consisting of three independent variables: sharing of information, shared decision-making, and exchange of electronic data. Data was gathered from 232 supply chain participants, including vendors, producers, and distributors. For data analysis, factor analysis and multiple regressions by SPSS were used. The finding of this study shows that two approaches to supply chain management, information sharing (IS), joint decision making (JDM), have a substantial impact. At the same time, operational efficiency is not substantially affected by Electronic Data Interchange (EDI). The present study has made a thorough review of the existing literature in the supply chain management area. Though the literature that focused on e-commerce business is scarce, the researcher has made every attempt to review all the relevant studies that happened so far. Based on an extensive literature review, it can be observed that a gap exists in studying the linkage among supply chain management components, supply chain performance, and organizational performance. It can also be noted that minimal effort has been made to empirically analyze and validate the relationship between supply chain performance and organizational performance.

\section{METHODOLOGY}

This research study aims to assess the association among important SCM components empirically, namely planning, inbound, outbound, returns, order management and how these critical components influence supply chain performance, which impacts the organizational performance. The present study framed the following objective of the study to enhance the limited literature available on supply chain management in the E-Commerce context: To study the relationship between supply chain performance and organizational Performance in E-Commerce organizations in India.

The following Hypotheses were framed for the present study

$\mathrm{H}_{\mathrm{a}} 01$ : There is a significant relationship between selected variables on SCM \& Organisational Performance

$\mathrm{H}_{\mathrm{a}} 02$ : There is a significant relationship between SCM performance and Organizational Performance

The present study is a descriptive type of research. Data was collected from both Primary and secondary sources.

Published By:

Blue Eyes Intelligence Engineering

\& Sciences Publication

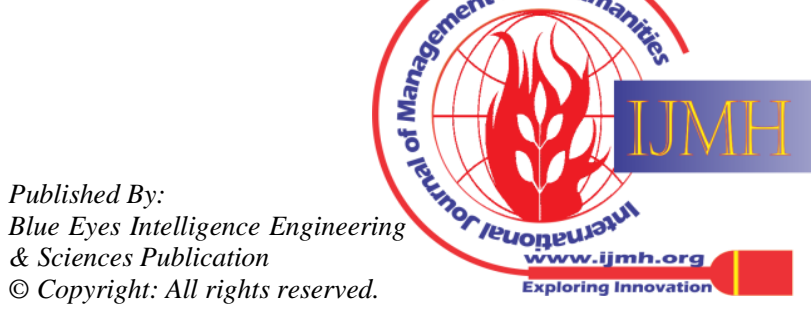


The primary data was collected by administering a structured questionnaire from the employees working in the selected E-Business organizations' supply chain management domain. The secondary data was collected from research articles, journals, company records, and manuals. Measures for the research constructs used in the present study were developed by seeking help from realtime professionals working in E-Commerce organizations with a framework borrowed and adapted by compiling various standard studies from prior literature.

Most of the items were measured using a 5-point Likert scale ranging from "very poor" to "excellent". The antecedents in our research model comprise five constructs. "Planning Performance of SCM" was assessed using six items; "Inbound Logistics Performance" was evaluated using eight items. Ten items are used to capture "Outbound Logistics Performance". "Returns Performance" was assessed using seven items. Ten items were used to assess "Order Management Performance". Finally, "Supply Chain Management Performance" and "Organisational Performance" were evaluated by using eight and nine items, respectively. Before the final questionnaire arrived, a pilot study with a sample size of 50 responses was performed. In order to verify the reliability of items used in the initial questionnaire, reliability analysis (Cronbach's alpha) was applied to show that Cronbach Alpha ranges from 0.7 to 0.9 (which is quite reliable). Based on reliability analysis and feedback from the supply chain managers working in ECommerce organizations, the final questionnaire was prepared.

The population universe consists of the employees working in India's supply chain management wing of the ECommerce organization. The present study has limited the scope by restricting the universe as an E-Commerce organization that only deals with fashion and lifestyle. A total of 100 questionnaires were distributed and collected from the employees working in Supply chain management in e-commerce organizations which are located in the Bangalore city, Karnataka.

\section{ANALYSIS}

The profile of the respondents includes age, gender, designation, and work experience. The distribution of respondents based on their characteristics is shown in table 1. Analytical aspects of these characteristics are worth noting.

Table-1: Profile of the Respondents

\begin{tabular}{|l|l|l|l|}
\hline Variables & Categories & Frequency & $\begin{array}{l}\text { Per } \\
\text { cent }\end{array}$ \\
\hline \multirow{4}{*}{$\begin{array}{l}\text { Age of } \\
\text { Respondent }\end{array}$} & $\begin{array}{l}\text { Less than } 30 \\
\text { years }\end{array}$ & 32 & 32.0 \\
\cline { 2 - 4 } & $\begin{array}{l}30-40 \\
\text { years }\end{array}$ & 35 & 35.0 \\
\cline { 2 - 4 } & $\begin{array}{l}\text { Above 40 } \\
\text { years }\end{array}$ & 33 & 33.0 \\
\cline { 2 - 4 } Total & 100 & 100.0 \\
\hline \multirow{3}{*}{ Gender } & Female & 18 & 18.0 \\
\cline { 2 - 4 } & Male & 82 & 82.0 \\
\cline { 2 - 4 } Total & 100 & 100.0 \\
\hline \multirow{2}{*}{ Designation } & $\begin{array}{l}\text { Executive } \\
\text { Level }\end{array}$ & 20 & 20.0 \\
\cline { 2 - 4 } & Team Lead & 56 & 56.0 \\
\hline
\end{tabular}

\begin{tabular}{|l|l|l|l|}
\hline \multirow{5}{*}{ Experience } & Level & & \\
\cline { 2 - 4 } & $\begin{array}{l}\text { Manager } \\
\text { Level }\end{array}$ & 24 & 24.0 \\
\cline { 2 - 4 } & Total & 100 & 100.0 \\
\hline & $\begin{array}{l}\text { Less than 5 } \\
\text { years }\end{array}$ & 28 & 28.0 \\
\cline { 2 - 4 } & $5-10$ years & 39 & 39.0 \\
\cline { 2 - 4 } & $\begin{array}{l}\text { Above 10 } \\
\text { years }\end{array}$ & 33 & 33.0 \\
\hline
\end{tabular}

The final sample $(\mathrm{N}=100)$ was composed of 82 males and 18 females. Thirty-five respondents are in the age group of '30 - 40 years', 33 respondents are in the age group of 'above 40 years' (36.1\%), and 32 respondents are in the age group of 'less than 30 years' (27.0\%). Designation wise, the majority of the respondents are at 'Team lead level' (N=56). Twenty respondents are at 'Executive level', and 24 respondents are managers. Similarly, majority of the respondents have experienced more than five years. Thirtynine respondents have experienced '5 - 10 years', 33 respondents have experience of 'above 10 years' in the supply chain department, and 28 respondents are freshers in the department with an experience of 'Less than 5 years. As the present study is based on the employees' perception towards supply chain practices, having more respondents from team lead level and good experience in supply chain departments will make the data collected more authenticate in this survey.

Table 2 is designed to exhibit the mean distribution of SCM performance and SCM variables along with organizational performance scale. From the table, it can be noted that the highest mean was observed to the scale 'Returns Performance' $\quad(\mathrm{M}=4.12)$ and 'Organizational Performance' $(\mathrm{M}=3.84)$, whereas low mean was observed to the scales 'Planning Performance' $(\mathrm{M}=3.35)$ and 'order Management Performance' (M=3.50).

Table-2: SCM \& ORGANIZATIONAL PERFORMANCE $(\mathrm{N}=100)$

\begin{tabular}{|l|l|l|l|}
\hline $\begin{array}{l}\text { S. } \\
\text { No }\end{array}$ & SCALE & Mean & S.D. \\
\hline 1 & SCM Planning Performance & 3.35 & 0.329 \\
\hline 2 & Inbound Logistics Performance & 3.63 & 0.399 \\
\hline 3 & Outbound Logistics Performance & 3.60 & 0.367 \\
\hline 4 & Returns Performance & 4.12 & 0.452 \\
\hline 5 & Order Management Performance & 3.50 & 0.372 \\
\hline 6 & $\begin{array}{l}\text { Supply Chain Management } \\
\text { Performance }\end{array}$ & 3.70 & 0.381 \\
\hline 7 & Organizational Performance & 3.84 & 0.364 \\
\hline
\end{tabular}

The present paper attempts to examine the relationship between supply chain performance and organizational performance with two hypotheses. The following deals with hypotheses testing by applying suitable statistical tools.

Ha1: There is no significant relationship between selected variables on SCM and Organizational Performance H01: There is a significant relationship between selected variables on SCM and Organizational Performance

Blue Eyes Intelligence Engineering \& Sciences Publication

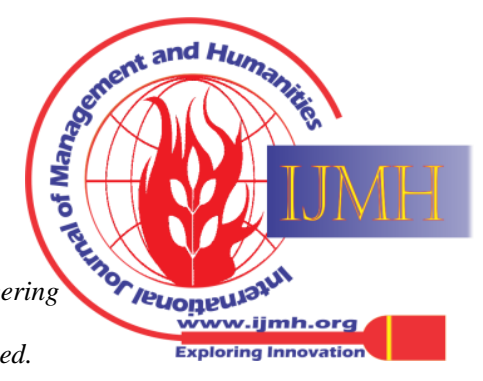




\section{Supply Chain Management and Organizational Performance: an Empirical Investigation with Special to E-Commerce Organizations in India}

The hypothesis is framed to test the statistically significant relationship between supply chain performance and organizational performance. To test this hypothesis, linear regression is employed by considering organizational performance as dependent variables and variable of the supply chain such as planning performance, Inbound, Outbound, Reverse and Order management performance as independent variables. Table 3a portrays the regression test results, giving that supply chain performance variables can explain $31.7 \%$ of organizational performance.

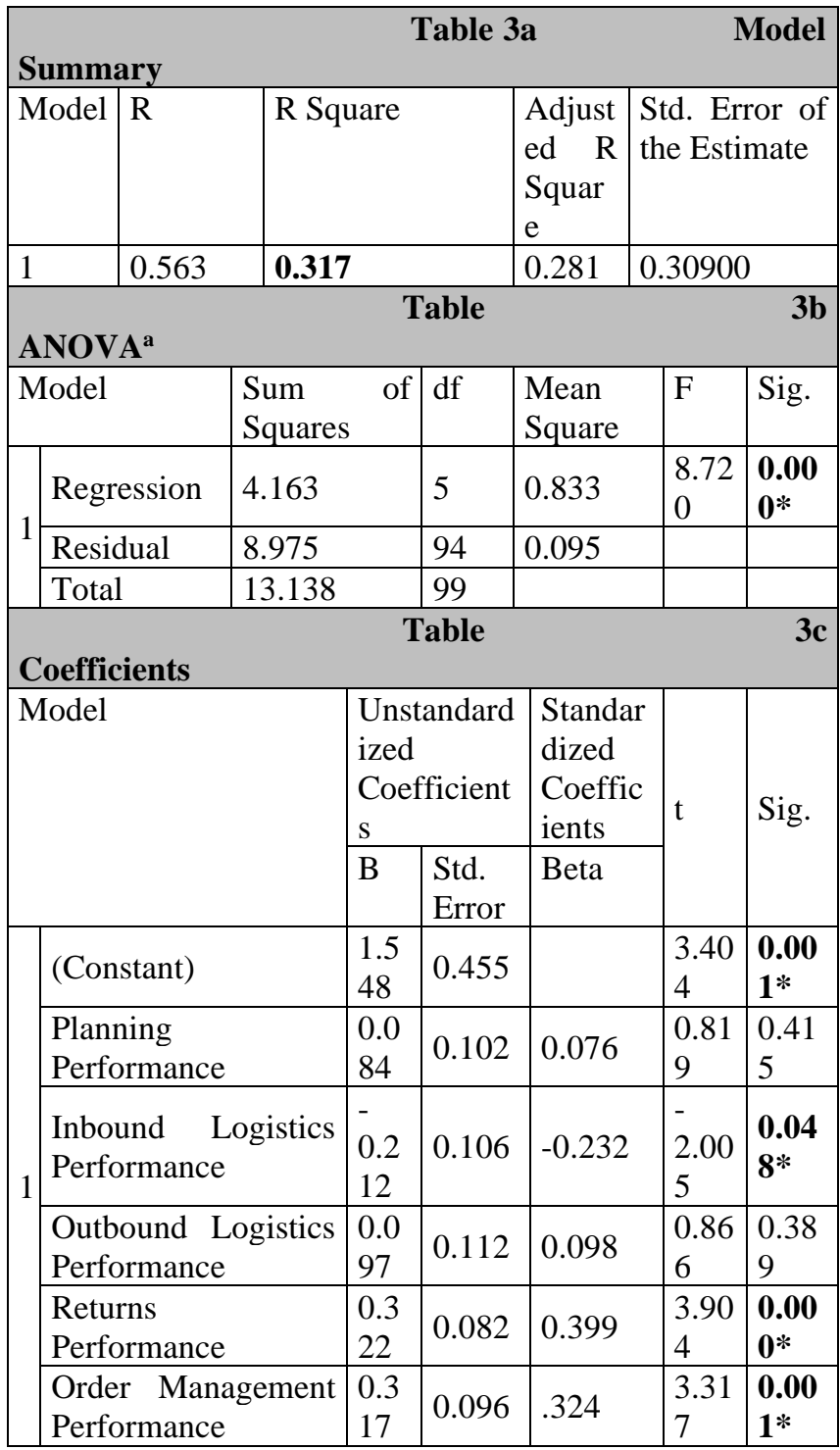

From table 3b, it can be inferred from the ANOVA test result that the overall model is significant. Table 3c shows that all the supply chain management variables significantly influence organizational performance except two variables: 'Planning performance and 'outbound performance'. Thus, the null hypothesis $\left(\mathrm{H}_{0} 1\right)$ is rejected from the regression analysis test results, and the alternate hypothesis $\left(H_{a} 1\right)$ is accepted.

H02: There is no significant relationship between SCM performance and Organizational Performance

Ha1: There is a significant relationship between SCM performance and Organizational Performance

This hypothesis is framed to examine the relationship between supply chain performance and organizational performance. The earlier hypothesis has considered the variables of supply chain management as independent variables. In this hypothesis, the supply chain management is regarded as an independent variable and organizational performance as a dependent variable. Linear regression is applied to examine the relationship between the two selected variables. Table $4 \mathrm{a}$ shows that $24 \%$ of organizational performance can be explained by supply chain management performance, which found to be consistent with the previous finding of the present study.

\begin{tabular}{|l|l|l|l|l|l|l|l|}
\hline \multicolumn{7}{|c|}{ Table 4a } \\
\hline Summary & & R Square & $\begin{array}{l}\text { Adjusted } \\
\text { Square }\end{array}$ & $\begin{array}{l}\text { Std. Error of } \\
\text { the Estimate }\end{array}$ \\
\hline 1 & 0.490 & $\mathbf{0 . 2 4 0}$ & 0.232 & 0.31917 \\
\hline \multicolumn{7}{|c|}{ Table } \\
ANOVA
\end{tabular}

Table $4 \mathrm{~b}$ and $4 \mathrm{c}$ have given a p-value less than 0.05 , which means that there is a statistically significant relationship between supply chain management performance and organizational performance. Hence, the null hypothesis $\left(\mathrm{H}_{0} 2\right)$ is rejected, and an alternative hypothesis $\left(\mathrm{H}_{\mathrm{a}} 2\right)$ is accepted.

\section{LIMITATIONS}

Any study based on a pre-designed questionnaire sample suffers from the inherent disadvantage of the probability of a disparity between what is reported and what is real, regardless of how thoroughly the questionnaire was designed and field study was carried out.

The study is confined to five E-Commerce organizations in Bangalore which becomes a limitation in generalizing the findings. The non-Probabilistic sample used in conducting the survey stands as another limitation of the present study. However, a combination of Quota and convenience sample was used while actual respondents were not randomly selected from the population.

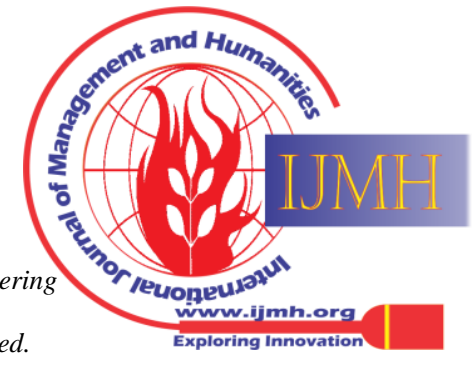


VI.

\section{CONCLUSION}

The study found that organizational performance can be attained by effective supply chain management. The supply chain management can be effective only if designed to meet the various planning, inbound, outbound, reverse and order management. The study found that planning and outbound are the key issues that significantly impact organizational purpose. The researcher found that the returns management and stock out situation are the key issues to address while studying supply chain management, especially in the e-commerce market.

As the study selected fashion and lifestyle segment, the returns management and stock-out situations are unavoidable. But still, efforts should be made to reduce the occurrence of these situations in the future. There are many issues to focus on detail like the website design, accessibility, return policy, inbound strategies, etc. Hence, further study is recommended to the researchers who shown interest in supply chain management.

\section{REFERENCES}

1. Frank Chen, Zvi Drezner, Jennifer K. Ryan, and David Simchi-Levi (2000), "Quantifying the Bullwhip Effect in a Simple Supply Chain: The Impact of Forecasting, Lead Times, and Information," Management Science, Vol. 46, No. 3, pp. 436 - 443.

2. Gunasekaran, A., Patel, C. and Ronald E. McGaughey (2004), "A framework for supply chain performance measurement", International Journal of Production Economics, Vol. 87, pp. 333 - 347.

3. https://learning.naukri.com/articles/supply-chain-in-times-of-ecommerce-boom/

4. https://www.cio.com/article/3311516/what-is-scor-a-model-forimproving-supply-chain-management.html

5. https://www.shiprocket.in/blog/ecommerce-supply-chainmanagement/

6. Jamal Ahmed Al-Doori (2019), "The Impact of Supply Chain Collaboration on Performance in Automotive Industry: Empirical Evidence", Journal of Industrial Engineering and Management, Vol. 12, No. 2, pp. 241 - 253. Accessed from https://doi.org/10.3926/jiem.2835

7. Jayaraman, R., Akash Srivastava, Ajit Balgi, Arun Kumar, V., and Baidyanath Prasad. (2013), "A Study of Operating Practices and Supply Chains in the e-commerce Online Retail Businesses in India”, Journal of Supply Chain Management Systems, Vol. 2, Issue. 3, pp. $33-47$.

8. Kurien, G. P. and Qureshi, M. N. (2011), "Study of Performance measurement practices in Supply Chain Management", International Journal of Business, Management and Social Sciences, Vol. 2, No. 4 , pp. $19-34$.

9. Martinez Veronica (2005), "What is the Value of Using Performance Management Systems?", Accessed from https://www.researchgate.net/publication/228900654_What_is_the_v alue_of_using_performance_management_systems (Retrieved on 12/09/2020)

10. Neely, A. (1998), "Measuring Business Performance”, Economist Books, London.

11. Nimna, V. P., (2017), "Role of supply chain management in ECommerce", International Journal of Advance Research and Development, Vol. 2, Issue. 10, pp. 60 - 64. Accessed from https://www.ijarnd.com/manuscripts/v2i10/V2I10-1174.pdf on 28/02/2018.

\section{AUTHORS PROFILE}

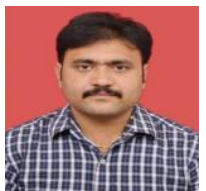

M. Sreenivasulu Reddy, Research Scholar, Department of Management Studies, School of Commerce, Management and Computer Science, Sri Venkateswara University, Tirupati-517502

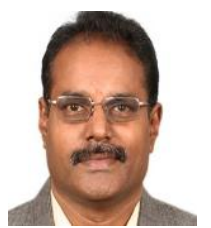

Dr. P. Raghunadha Reddy, Professor \& Research Supervisor, Department of Management Studies, School of Commerce, Management and Computer Science, Sri Venkateswara University, Tirupati -517502 